\title{
Tourist Destinations as Integrated System: A Khorezm Region's Perspective on Achieving Competitiveness
}

\author{
Ismailov Adhambek Bakhramovich \\ Department of Tourism, Tourism and Economics Faculty, Urgench State University, Urgench City, Uzbekistan \\ Email address: \\ goodluck_0714@mail.ru \\ To cite this article: \\ Ismailov Adhambek Bakhramovich. Tourist Destinations as Integrated System: A Khorezm Region's Perspective on Achieving \\ Competitiveness. International Journal of Management and Fuzzy Systems. Vol. 4, No. 2, 2018, pp. 15-18. \\ doi: 10.11648/j.ijmfs.20180402.11
}

Received: July 1, 2018; Accepted: July 12, 2018; Published: August 4, 2018

\begin{abstract}
The paper deals with the analysis of the role of regional tourism organizations as integrated for the perspective on achieving competitiveness of tourism industry in the Khorezm region. Also actual problems of integration of tourist enterprises in the region and the main problems, tendencies of development of the tourist industry in the region are studied. In contrast to traditional production, determining the degree of dependence of the tourism industry on non-productive sectors on any internal or external factors can be the basis for the development of the industry's future strategy. In keeping with the above, it is essential that the focus should be on linking a particular aspect of innovation management to the industry in the proper organization and effectiveness of strategic planning in the economic sectors.
\end{abstract}

Keywords: Tourism, Touristic Business, Strategy, Strategic Management, Innovation Management, Region, Investment

\section{Introduction}

In the last year, in order to ensure the participation of tourism in Uzbekistan in the process of sustainable development, the President of the Republic of Uzbekistan has developed and implemented many program of measures, large investment projects, and various legal documents. In a word, it is a complex development of the industry throughout the country. Particularly, taking into consideration the realistic analysis of the socio-economic situation of the regions, and the specificity of tourism for each region, the strategic importance of the tourism industry of the country is emphasized.

In particular, the head of the state said that on May 4 this year, 11.226 billion soums will be spent on the implementation of the projects envisaged by the Resolution of the President of the Republic of Uzbekistan "On the Program of Complex Development of the Tourism Potential of Khorezm Region and Khiva in 2017-2021", including tourism infrastructure, a special attention is being paid to the development of the system, strengthening the materialtechnical base of modern facilities. [1] In this context, il to study the integration of tourism enterprises and services based on the introduction of strategic and innovative management approaches is desirable.

Nowadays this area is one of the key issues in the world economy. Scientists of the world offer different models for the development of tourism. The first factor is features of integration in the field of tourism. The book by Cornelissen attempts to show the real state and prospects for the development of the integration space, including in the sphere of international tourism. The author's book focuses on the political economy of the global tourism system in the era of globalisation, and its impacts in developing contexts. It uses case study analysis of South Africa, a country that has emerged as an increasingly popular international destination since the end of apartheid, but whose sector had been greatly shaped and often constricted by outside factors, to assess how tourism as a global system of trade, production, exchange and governance play out in developing countries and what its benefits and disadvantages are for them. [2]. Besides, Pizzitutti, Francesco [3], Colomo P., Ricardo [4], Della Spina, L. [5], Perreault, S. G., Black, S. J., Denlinger, T. R., Koskay, K. A. and Poirier, G. J [6], Kristjánsdóttir, K. R., Ólafsdóttir, R. and Ragnarsdóttir, K. V. [7], Cross, J. and Westley, A. [8], Ajala, O. A. and Aliu, I. R. [9], Lau, P. L., Koo, T. T. and Dwyer, L. [10] also researched in this field. The conceptual approach has been developed by many local 
and foreign researchers to explore the integration process of tourist companies. In particular, researchers J. P. Bousset, D. Skuras, J. Tesitel, J. B Marsat, A. Petrou, E. Fiallo-Pantziou, D. Kuová, M. Barto that tourism and regional resources, products, and relationships in general are among the main factors contributing to the development of integrated tourism. First of all it is necessary to identify the appropriate institutional structures and strategies for the management of regional tourist resources management, tourist companies, land management, transport and excursion services [11]. According to Quartolina, new information technologies and efficient relationships serve to the rapid development of tourism and the creation of vertical, horizontal and diagonal integration [12]. In his research on the role of clustering in the development of tourism business in the regions, V. E. Shimokova noted that enterprises engaged in tourist activity in the market conditions are provided through the efficiency of business structures, integrated communication based on the innovative resource accumulation mechanism and information communication technologies in tourism management [13].

\section{Method}

According to A. Machiavelli, "tourist destination can be turned into a product only by implementing an integrated bidding system for tourists. Interaction between business entities at the same time benefits the tourist destination and the business, but most operators do not understand this." [14]

Scientists in tourism management, M. Frank and R. Govers, in their research on "Integrated quality management for tourist destinations: European prospects for competition", say "tourist destinations should have elements such as integrated, political, strategic and quality management approaches to integrate [15].

Indeed, the authors have highlighted the importance of integration of tourism into a regional economy with clear analysis, which is crucial to continuing its work, technical and technological and local analysis of the industry.

The methodology of the research was used in the methods of empirical research, systematic and comparative analysis, statistical grouping, and echo evaluation

\section{Analyses and Results}

In contrast to traditional production, determining the degree of dependence of the tourism industry on nonproductive sectors on any internal or external factors can be the basis for the development of the industry's future strategy. In particular, the prospects for the creation of economic clusters on the ground of studying the existing capacities of business-friendly entities are offered at the regional and local levels. In the analysis of tourist potential of our country, the development of tourist regions plays an important role. Today, Khorezm region, unlike the tourist zones of Samarkand, Bukhara and Tashkent, is the most populous tourist destination in the country. With regard to the region's tourist capacity, tourists flow and the share of tourism in the gross regional product, the area indicates the need for more efficient use of available resources.

In Khorezm region, by the year 2016, 81658 tourists visited local tourist agencies and organizations, including 28868 domestic tourists and 52,790 foreigners. For the first 9 months of 2017, 95,558 tourists were served, 34,985 domestic tourists, 60,573 tourists were foreign tourists, ie foreigners. The figure for the first 9 months of 2017 has increased by $17 \%$ compared to 2016 . Looking at the touristic organizations operating in the region, we can identify the industry's potential for development. In particular, 21 private entrepreneurship entities operate in the tourism sector of the country.

During the past year 2016, Zuxro Travel LLC (12089), Bek Tour LLC (9600) and Jawhar Hulkar Yulduzi LLC have been leading the market with 9,200 tourists (Figure 1).

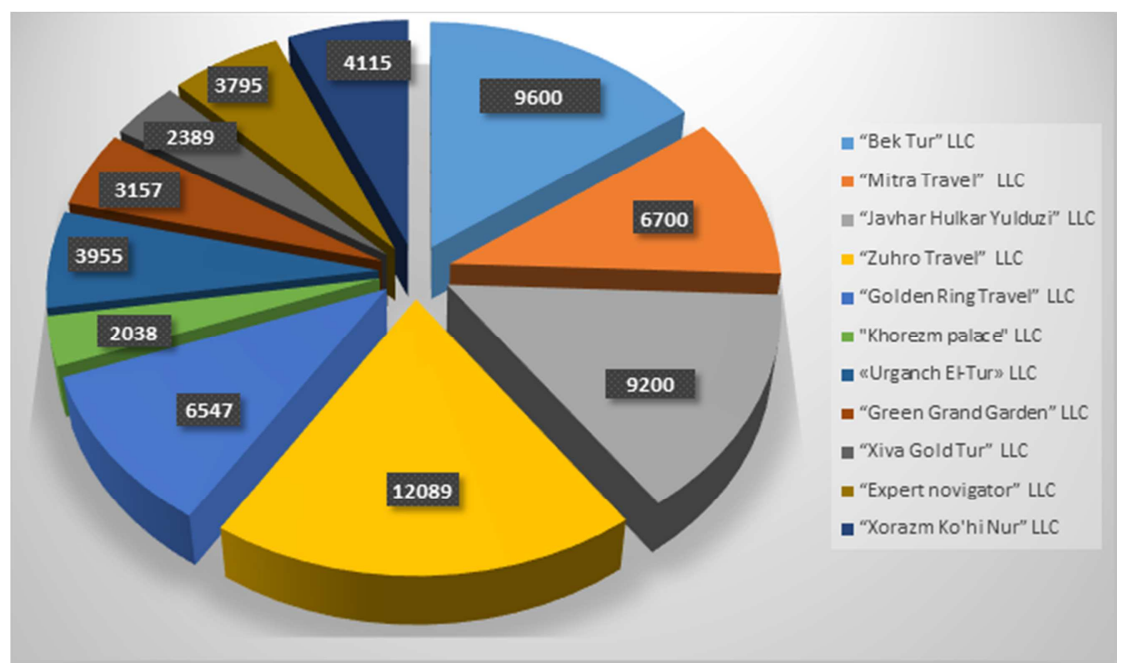

Figure 1. Indicators of tourist attraction in 2016 by major tour operators in Khorezm region.

Of course, the high share of tourist services in the export trade is ensured by the fact that the number of foreign visitors is high, and that foreign currency will enter the country.

By 2016, enterprises operating in the tourism sector of the 
region have attracted 52,790 foreign tourists during the first nine months of 2017 , including 60,573 tourists. If we analyze tourists from the point of view of accommodation, today in Khorezm region, 48 hotels serve 2016, both for foreign and local residents. These hotels are fully booked during the tourist season. However, average annual employment rates are not stable. In 2016 this figure was $19 \%$, and by the end of the first 9 months of 2017 it reached 24\%. The Asia Khiva Hotel in the province has served 13537 visitors in 2016, which is 10679 in the first 9 months of 2017 (see Figure 2).

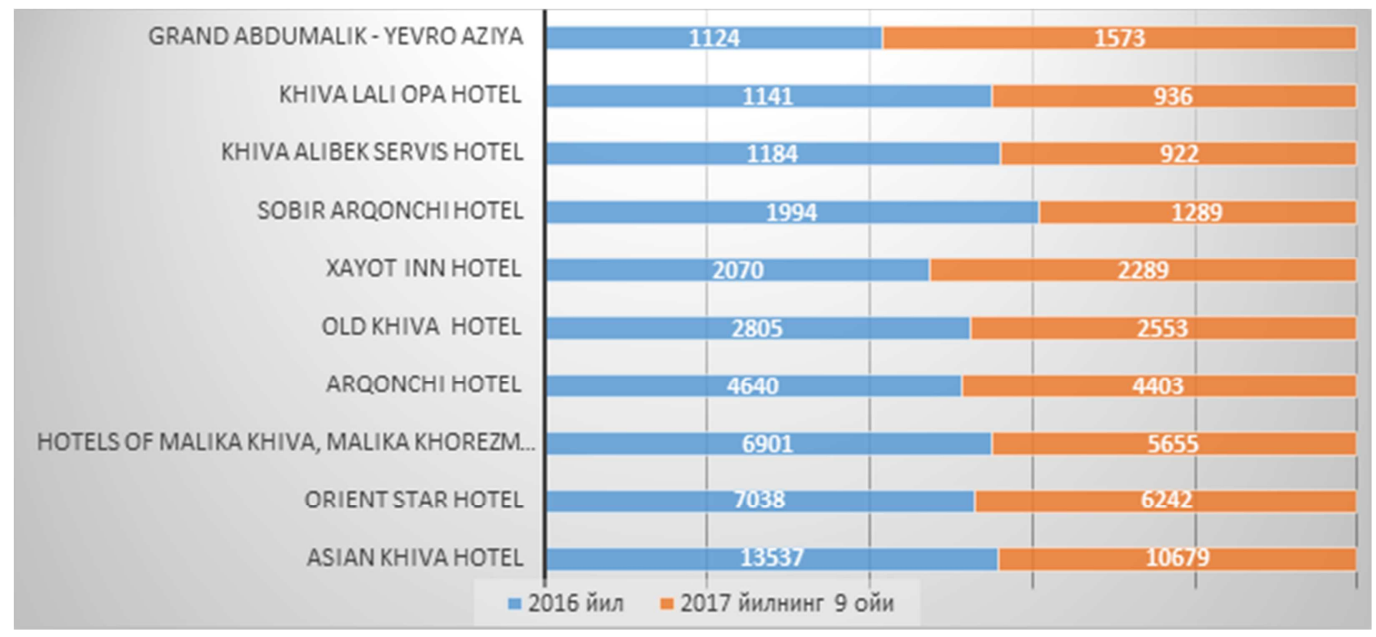

Figure 2. Employment rates for large hotels in Khorezm region for 2016-2017.

Moreover, the above-mentioned indicators analyze that integration in the tendency of development of tourist organizations and hotels in the region is of high importance. Located in the region, regional branches of hotels and large tourist enterprises occupy the main part of the market. Moreover, in the near future, the further increase in their number will indicate the urgency of the problem. Taking into account the high level of the hotel industry in the direction and direction of tourist flows by touristic enterprises, this year measures on construction and reconstruction of 18 hotels in Khorezm region were initiated by the head of the state in 2017-2021 [16].

In general, the increase in the number of hotels and nongovernmental organizations working in such tourism sectors and the number of hotels necessitates development of strategic development programs in this sector. The introduction of strategic planning and innovative management in the economy into a particular sector of the economy requires initially vertical and horizontal integration. Local tour companies are unable to effectively utilize the experience of foreign travel companies in the field of integration processes, leading to a lack of competitiveness of their products [17].
Within the framework of this research, the most important interest for us is the last classification, taking into account the scale and novelty of innovations, the intensity of innovative change most expresses the quantitative and qualitative characteristics of innovations in any area of the economy and they are important for the economic evaluation of their consequences and the rationale for management decisions.

As mentioned above, different approachs to the determination of the main directions of innovative activity in tourism were shown by the scientists in their works. According to their opinions, the main directions of innovative activity of tourist enterprises are the use of new equipment and technologies in the provision of traditional services, the introduction of new services with new properties, changes in the organization of production and consumption of traditional tourist services, the use of new tourist resources previously unused, the identification and use of new markets sale of tourist services and goods. Having considered the proposed options, we propose to combine and strengthen the approaches, taking into account the earlier definition of the economic category "innovation activity in tourism" and to consider the main directions of innovation activity; depending on the process, they concern (Table 1).

Table 1. The main directions of innovation in tourism.

\begin{tabular}{|c|c|c|c|}
\hline \multirow{2}{*}{$\begin{array}{l}\text { Type of } \\
\text { innovation }\end{array}$} & \multicolumn{3}{|l|}{ Type of process } \\
\hline & Formation & Promotion & Implementation \\
\hline radical & $\begin{array}{l}\text { use in the production of innovative products } \\
\text { and services of new tourist resources } \\
\text { previously unused }\end{array}$ & $\begin{array}{l}\text { use of new techniques and technologies in } \\
\text { promoting traditional services }\end{array}$ & $\begin{array}{l}\text { the emergence of a new consumer and } \\
\text { a new market for tourism services }\end{array}$ \\
\hline combinatorial & $\begin{array}{l}\text { introduction of services with new properties } \\
\text { in a respectable tourist product }\end{array}$ & $\begin{array}{l}\text { promotion of traditional tourist services with the } \\
\text { use of new, for these services, marketing moves }\end{array}$ & $\begin{array}{l}\text { identification and use of new markets } \\
\text { for tourism services }\end{array}$ \\
\hline improving & $\begin{array}{l}\text { changes in the organization of traditional } \\
\text { tourism services }\end{array}$ & $\begin{array}{l}\text { improving the organization of promotion of } \\
\text { traditional tourism services }\end{array}$ & $\begin{array}{l}\text { preservation and strengthening of } \\
\text { market positions of tourist enterprises }\end{array}$ \\
\hline
\end{tabular}


Taking into account the interpretation of the types of innovations and taking into account the sectoral component of innovation activity, we determined the main directions of innovative activity in tourism.

\section{Conclusion}

At the same time, it is possible to achieve high efficiency by applying the following suggestions in support of integration of local touristic enterprises, based on available opportunities:

Development of a system for the establishment of a touristic association "crowdfunding" in Khorezm as a nonprofit organization;

Formation of a web platform for the establishment of information and communication integration of destinations using modern information technologies and attracting all tourist enterprises to the platform;

development and implementation of the state cooperation program for establishing cooperation of local tour operators with large foreign insurance companies;

development of projects on attraction of investments into state investment programs aimed at increasing their charter capacities for further development of cooperation with the foreign tourist enterprises of the region;

organization of monitoring of economic potential of integration of tourist enterprises under the local authorities.

In keeping with the above, it is essential that the focus should be on linking a particular aspect of innovation management to the industry in the proper organization and effectiveness of strategic planning in the economic sectors. Therefore, the localization of world experience in this field of tourism will contribute to augmenting the share of the sector in direct GDP. This requires the elaboration of scientific research projects covering the principles of sustainable macroeconomic indicators and the socio-economic development of regions.

\section{References}

[1] The President of the Republic of Uzbekistan Sh.Mirziyoev, May 4, 2017 Resolution by the President of the Republic of Uzbekistan "On the Program of comprehensive development of tourism potential of Khorezm region and Khiva city in 2017-2021" № PQ-2953.

[2] Cornelissen S., 2017. The global tourism system: Governance, development and lessons from South Africa. Routledge.

[3] Pizzitutti, Francesco, et al. "Scenario planning for tourism management: a participatory and system dynamics model applied to the Galapagos Islands of Ecuador." Journal of Sustainable Tourism 25.8 (2017): 1117-1137.
[4] Colomo-Palacios, Ricardo, et al. "Towards a social and context-aware mobile recommendation system for tourism." Pervasive and Mobile Computing 38 (2017): 505-515.

[5] Della Spina, L., 2017, July. Integrated evaluation and multimethodological approaches for the enhancement of the cultural landscape. In International Conference on Computational Science and Its Applications (pp. 478-493). Springer, Cham.

[6] Perreault, S. G., Black, S. J., Denlinger, T. R., Koskay, K. A. and Poirier, G. J., Thomson Reuters Global Resources Unlimited Corp, 2017. Method and system for integrated professional continuing education related services. U.S. Patent $9,792,583$

[7] Kristjánsdóttir, K. R., Ólafsdóttir, R. and Ragnarsdóttir, K. V., 2018. Reviewing integrated sustainability indicators for tourism. Journal of Sustainable Tourism, 26(4), pp. 583-599.

[8] Cross, J. and Westley, A., Oracle International Corp, 2017. Integrated communication system and method. U.S. Patent $9,641,345$.

[9] Ajala, O. A. and Aliu, I. R., 2017. Tourism and integrated development: A geographic perspective. Geografia-Malaysian Journal of Society and Space, 9(1).

[10] Lau, P. L., Koo, T. T. and Dwyer, L., 2017. Metrics to measure the geographic characteristics of tourism markets: An integrated approach based on Gini index decomposition. Tourism Management, 59, pp. 171-181.

[11] J. P. Bousset, D. Suras, J. Tesitel, J. B Marsat, A. Petrou, A decision support system for integrated tourism development: rethinking tourism policies and management strategies. Tourism Geographies, Taylor \& Francis (Routledge), 2007, 9 (4), p. 387 - p. 404.

[12] Kvartalnov V. A Tourism / Kvartalnov V. A.: Uchebnik. - M: Finance statistics, 2004. - 320 p.

[13] Shimakova V. Y., The Role of Clustering in the Development of the Tourist Business in Regions, Shimakova, VE: Culture of the Peoples of the Black Sea Region. Science Magazine. 2008. - No. 137. - P. 62-66.

[14] Andrea Macchiavelli, (2001) "Tourist destinations as integrated systems", Tourism Review, Vol. 56 Issue: 3/4, pp. 6-11, https://doi.org/10.1108/eb058361

[15] Frank M. Go*, Robert Govers "Integrated quality management for tourist destinations: a European perspective on achieving competitiveness" Tourism Management 21 (2000) 79-88.

[16] Speech by President of the Republic of Uzbekistan Shavkat Mirziyoev at the extraordinary session of the Council of People's Deputies of Khorezm region / http://president.uz/en/lists/view/1147

[17] Melnichenko S. V. Information technologies in tourism: theory, methodology, practice: Monograph. - Kiev Tradeeconomics. University, 2008. - 493 p. 